\title{
Analisis Gerakan Tari Saman Ditinjauan Dari Konsep Kebugaran Dan Konsep Gerakan Dasar
}

\author{
Aldiansyah Akbar ${ }^{1}$, Hasan Saini ${ }^{2}$ \\ Fakultas Keguruan dan Ilmu pendidikan Universitas Serambi Mekkah, \\ Email.aldiansyah.akbar@gmail.com
}

\begin{abstract}
Abstrak
Tari saman merupakan sebuah tari tradisional yang berkembang secara turun-temurun di daerah Gayo Lues. Kegiatan saman dilakukan oleh laki-laki dalam posisi duduk bersimpuh dan kegiatan inti dari tari ini adalah gerakan tangan serta kepala dan jangin (syair). Bila dilihat dari bentuk gerakan, tari ini mengandung unsur-unsur gerak kebugaran dan gerakan dasar. Sehubungan dengan hal tersebut, maka penelitian ini bertujuan untuk menganalisis gerakan tari saman ditinjau dari unsur-unsur kebugaran jasmani dan gerakan dasar. Jenis penelitian ini adalah penelitian evaluasi dengan metode deskriptif dan pendekatan kualitatif dan kuantitatif. Adapun subjek dalam penelitian ini adalah melalui jugde (ahli) sebanyak 5 orang, dengan teknik pengumpulan data dilakukan melalui dokumentasi video tari saman Pemda Gayo Lues. Selanjautnya data dianalisis dengan menggunakan rumus rata-rata dan persentase. Dan dapat disimpulkan bahwa (1) gerakan tari saman ditinjauh dari konsep kebugaran jasmani adalah terdapatnya $66 \%$ gerakan tari saman agak sesuai dengan unsur kebugaran jasmani dan 34\% terdapat gerakan tari saman sesuai dengan kebugaran jasmani. (2) gerakan tari saman yang ditinjau dari konsep gerakan dasar adalah terdapat $56 \%$ gerakan tari saman agak sesuai dengan gerakan dasar dan $44 \%$ terdapat gerakan tari saman sesuai dengan gerakan dasar.
\end{abstract}

Kata Kunci: Tari Saman, Kebugaran, Konsep Gerakan Dasar

\section{PENDAHULUAN}

Masyarakat Aceh yang terdiri atas berbagai suku mempunyai kebudayaan dan kesenian masing-masing yang masih dipelihara oleh masyarakatnya, kesenian tradisional Aceh yang masih berakar pada masyarakat. Kesenian tradisional dari daerah Aceh sekarang ini .sudah banyak dikenal di tingkat nasional, misalnya tari Seudati yang dimainkan suku Aceh, tari saman yang dimainkan suku Gayo, tari Rapa'i yang dimainkan suku Aceh, dan lain-lain. Tari-tari yang disebutkan tadi bukan lagi merupakan kata asing bagi masyarakat Aceh dam juga masyarakal Indonesia. jika ada orang mengucapkan kata-kata Seudati, Saman, Rapa'i, orang dengan mudah mengetahui bahwa kata itu adalah nama kesenian popular dari Provinsi Aceh.

Menurut Salam (2011:71) Seni tari dalam saman mengekspresikan gerak tubuh. Dari gerak tubuh ini, yang paling dominan adalah gerak tangan. Disusul dengan gerak badan dan gerak kepala. Sementara kaki dalam posisi berlutut hanya berfungsi untuk menyangga keseimbangan antara gerak tangan, badan, dan kepala. Gerak dalam saman mempunyai makna masing-masing, yaitu: (1) Pendahuluan, gerakan pendahuluan, tepuk tangan, gerakan memukul dada, gerakan memukul paha, goncangan kepala, 
gerakan badan, goncangan badan, gerakan surang-saring (selang-seling), gerakan lentur badan.

Seorang penari saman memiliki kebugaran jasmani yang optimal, maka dalam melakukan tari saman itu tanpa merasakan lelah yang berlebihan walaupun sangat membutuhkan fisik yang sehat. Tetapi sebaliknya jika penari saman tidak memiliki kemampuan fisik yang tinggi, maka seorang penari saman akan terasa berat dan lelah. Dengan kebugaran jasmani penari saman yang sehat maka untuk menampilkan tari saman akan bersemangat dan mendapatkan hasil yang sesuai hasil yang diharapkan, dimana dalam tari saman sangat membutuhkan fisik yang kuat, karena apabila seorang penari tari saman tidak memiliki kebugaran tubuh yang baik.

Penari saman akan mengalami hal-hal yang tidak diinginkan seperti kesakitan dalam tepukan dada, mudah lelah dan konsentrasi terganggu, tentunya didalam seni tari saman memiliki dan membutuhkan suatu aspek kebugaran jasmani yang sangat terlihat dalam tari saman seperti, daya tahan, kelentukan, kelincahan, kecepatan, keseimbangan dan ketepatan, dalam hal kebugaran jasmani tersebut sangatlah harus dimilki seorang penari tari saman sehingga akan terlihat fisik seorang penari saman baik atau tidaknya dalam melakukan gerakan dalam tari saman, sehingga komponen kebugaran jasmani sangat mendukung dalam gerakan tari saman dan akan berdampak dalam kesehatan seorang penari tari saman.

Dari latar belakang masalah yang dipaparkan di atas, maka perlu adanya pengkajian tentang gerakan tari saman dilihat dari kebugaran dan konsep gerakan, maka peneliti ingin menyimpulkan bahwa ingin meneliti tentang "Analisis Gerakan Tari Saman Dari Tinjauan Kebugaran Dan Konsep Gerakan”.

\section{Tujuan Penelitian}

Adapun yang menjadi tujuan dalam penelitian ini adalah:

1. Untuk menganalisis gerakan tari saman ditinjauan dari unsur-unsur kebugaran jasmani

2. Untuk menganalisis gerakan tari saman ditinjauan unsur-unsur gerak dasar.

\section{TINJAUAN PUSTAKA}

\section{Pengertian Tari Saman}

Menurut Bahry (2005:3) Tarian ini di namakan saman karena diciptakan oleh seorang Ulama Gayo bernama Syekh Saman pada sekitar abad XIV Masehi, dari dataran tinggi Gayo. Awalnya, tarian ini hanyalah berupa permainan rakyat yang dinamakan Pok Ane. Namun, kemudian ditambahkan iringan syair-syair yang berisi puji-pujian kepada Allah SWT, serta diiringi pula oleh kombinasi tepukan-tepukan para penari. Saat itu, tari saman menjadi salah satu media dakwah.

Menurut Bahry (2005:9) Tari saman merupakan kesenian saman yang berasal dari kata arab, yaitu saman yang berarti delapan, pendapat ini menyebutkan bahwa tarian ini pada awalnya dilakukan oleh delapan orang, sehingga dinamai saman. Menurut Bahry (2014:11) Tari saman merupakan seni pertunjukan dari Indonesia yang kedua, setelah wayang, diakui oleh Unesco sebagai warisan dunia takbenda. Proses yang ditempuh oleh pemerintah dalam mencapai hasil ini bukanlah pekerjaan yang mudah. Akan tetapi, berkat kegigihan pemerintah Indonesia, pemerintah Aceh, dan 
juga Pemda Kabupaten Gayo Lues, hal ini dapat dicapai. Ada hal lain lagi yang membuat bangsa Indonesia bangga tentang tari saman yakni pengajuan tari saman ke Unesco pada tahun 2010 dan pada tanggal 24 November 2011 sudah ada pengakuan dari Unesco. Sementara pihak Unesco mengatakan ada yang sudah mengajukan usulan ke Unesco sudah mencapai tiga tahun, namun belum juga mendapat pengakuan. Dari cerita singkat ini dapat dipahami bahwa pengakuan Unesco ini bukan rekayasa dari pemerintah, melainkan kenyataan yang ada pada tari saman itu memang benar-benar hal yang menakjubkan. Tim Unesco menemukan bahwa setiap kampung yang berada di Kabupaten Gayo Lues pasti memiliki tari saman dan juga setiap belah (bagian dari kampung) ada grup tari Saman.

Tari saman mulai dikenal atau sudah mulai populer di Aceh (di luar suku Gayo) sebenarnya pada tahun 1972 yakni waktu Pekan Kebudayaan Aceh (PKA) ke-2. Tari saman yang mewakili Aceh Tenggara (waktu itu Kabupaten Gayo Lues belum ada dan Aceh Tenggara juga masih daerah persiapan untuk pemekaran dari kabupaten Aceh Tengah), menjadi tari yang sangat digemari atau favorit pada PKA ke-2. Ibu Tien Soeharto sangat menyenangi tari ini dan juga Menteri Penerangan, Budihardjo, juga memuji-muji tari saman ini sehingga beliau menjuluki tari saman dengan nama "Tari Tangan Seribu".

\section{Hakikat Kebugaran Jasmani}

Beberapa definisi mengenai kebugaran fisik yang dikemukakan oleh beberapa ahli. Kebugaran jasmani adalah kemampuan seseorang untuk melakukan suatu pekerjaan tertentu dengan cukup baik, tanpa mengakibatkan kelelahan, Widiastuti (2017:13). Kebugaran didefinisikan sebagai kemampuan tubuh untuk melakukan suatu tugas rutin dalam jangka waktu yang cukup lama tanpa mengalami kelelahan yang berarti dan masih memiliki tenaga cadangan untuk melaksanakan aktivitas yang bersifat mendadak, Nala (2011:30).

Pengertian lain menyatakan Kebugaran fisik adalah kemampuan tubuh untuk melakukan tugas dan pekerjaan sehari-hari dengan giat, tanpa mengalami kelelahan yang berarti serta dengan cadangan energi yang tersisa ia masih mampu menikmati waktu luang dan menghadapi hal-hal darurat yang tidak terduga sebelumnya, Wahjoedi (2001:27).

Mukhlolid (2004:3) pengertian kebugaran Jasmani adalah kemampuan dan kesanggupan untuk melakukan aktivitas atau kerja, mempertinggi daya kerja dengan tanpa mengalami kelelahan yang berlebihan. Ismaryati (2006:40), pengertian kebugaran jasmani adalah kondisi yang menggambarkan kemampuan seseorang untuk melakukan tugas dengan produktif tanpa mengalami kelelahan yang berlebihan.

\section{Fungsi Kebugaran jasmani}

Latihan kebugaran jasmani adalah aktivitas olahraga yang dilakukan untuk meningkatkan daya tahan tubuh dan kekuatan otot, serta melatih kelenturan dan keseimbangan. Olahraga ini juga efektif untuk membakar kalori dan menurunkan risiko terjadinya sejumlah penyakit.

Latihan kondisi fisik (physical conditioning) memegang peranan yang sangat penting untuk mempertahankan atau meningkatkan derajat kebugaran jasmani (physical 
fitness). Proses latihan kondisi fisik yang dilakukan secara cermat, berulang-ulang dengan kian hari meningkat beban latihannya, kemungkinan kebugaran jasmani seseorang semakin meningkat. Hal ini akan menyebabkan seorang kian terampil, kuat dan efisien dalam gerakannya

Berikut adalah fungsi kebugaran jasmani, baik untuk fisik maupun mental, jika dilakukan secara rutin:

a. Menjaga berat badan

b. Mengontrol kadar gula darah

c. Mengurangi risiko terkena penyakit kardiovaskular.

d. Menjaga kesehatan tulang

e. Memperbaiki mood

f. Mengurangi stres dan depresi

\section{Komponen Kebugaran Jasmani}

Disetiap komponen kondisi fisik sangatlah penting untuk dilatih pada tari untuk meningkatkan kemampuan gerak fisik dalam tari saman, ada beberapa komponen fisik, menurut Nala (2002:21) yaitu sebagai berikut: (1) kekuatan (strenght) adalah jumlah aktifitas yang dapat dilakukan dalam satu-satuan waktu, di dalam daya ledak ini ada tiga komponen yang tersangkut yaitu kekuatan otot, jarak dan waktu, (2) daya tahan (endurance) adalah kemampuan tubuh dalam melakukan aktivitas terus menerus yang berlangsung cukup lama, (3) kecepatan (speed) adalah kemampuan untuk mengerjakan suatu aktivitas berulang yang sama serta berkesinambungan dalam waktu yang singkatsingkatnya, (4) kelentukan (flexibility) adalah kesanggupan tubuh atau anggota gerak tubuh untuk melakukan gerakan pada sebuah atau beberapa sendi seluas-luasnya, (5) kelincahan (agility) adalah kemampuan tubuh atau bagian tubuh untuk mengubah arah gerak secara mendadak dalam kecepatan yang tinggi, (6) reaksi (reaction) daya otot disebut juga dengan daya ledak otot (explosive power) adalah kemampuan seseorang dalam menggunakan kekuatan maksimum yang dikerahkan dalam waktu sesingkat-singkatnya, (7) koordinasi (coordination) adalah kemampuan tubuh untuk mengintegrasikan berbagai gerak yang berbeda menjadi gerak tunggal yang harmonis dan efektif, (8) keseimbangan (balance) merupakan kemampuan seseorang mengendalikan organ-organ syaraf otot sehingga dapat mengendalikan gerakangerakan dengan baik dan benar, (9) ketepatan (accuracy) adalah kemampuan seseorang untuk mengendalikan gerak- gerak bebas terhadap suatu sasaran.

\section{Hubungan Tari Saman Dengan kebugaran Jasmani}

Tarian dapat menyehatkan tubuh, karena tari adalah aktifitas fisik yang lebih banyak melakuan gerak dengan kelincahan tubuh, kelenturan tubuh, daya tahan dan power yang akan benyak membakar energi dalam tubuh dan aktivitas kardiovaskular akan meningkat seperti kita berolahraga.Badan sehat dan bugar, tentu menjadi idaman setiap orang. Namun tak setiap orang benar-benar tahu pasti bugar tidaknya tubuh masing-masing sebelum di tes dengan tes kebugaran.

Kebugaran kardiorespiratori adalah kemampuan jantung dan paru-paru untuk menyerap dan memanfaatkan oksigen selama latihan fisik. Latihan yang teratur dalam kegiatan aerobik biasanya akan meningkatkan daya tahan tubuh dengan memperkuat 
otot jantung dan meningkatkan volume paru-paru. Sejumlah tes biofisik, termasuk volume konsumsi oksigen maksimal ( $\mathrm{VO}_{2}$ max) pemantauan denyut jantung, dan tes shuttle run digunakan untuk mengukur daya tahan kardiorespirasi. $\mathrm{VO}_{2}$ max digunakan untuk mengukur kebugaran kardiorespiratori seseorang selama melakukan latihan.

\section{Hubungan Tari Saman Dengan Gerakan Dasar}

Seni merupakan salah satu hasil karya manusia yang mempunyai nilai kreativitas tinggi dan sering mengalami perubahan seiring berkembangnya zaman. Salah satunya adalah seni tari yang dalam beberapa kegiatan sering menjadi bagian di dalamnya, baik itu dalam upacara-upacara adat tertentu maupun pagelaran seni yang sifatnya menghibur. Keberadaan seni tari dengan lingkungannya merupakan masalah sosial yang cukup menarik. Beberapa tarian tradisional tertentu saja, yang dapat mengemuka dan dapat dinikmati oleh masyarakat. Hal tersebut dikarenakan tarian tradisional masih eksis dilingkungannya, artinya masyarakat masih menerima dan melestarikan keberadaan tarian tradisional tersebut (Syahroni, 2012).

Media ungkap tari adalah gerak. Gerak tari merupakan gerak yang diperhalus dan diberi unsur estetis. Gerak dalam tari berfungsi sebagai media untuk komunikasi. Kompetensi dasar dalam mempelajari seni tari mencakup praktik dasar dan mahir dalam penguasaan gerak tari meliputi tari tradisional maupun tari garapan, kemampuan memahami arah dan tujuan koreografer dalam konsep koreografi kelompok (Setiawati, 2008).

Keterampilan tari yang dimiliki dapat dibentuk melalui kesiapan organ-organ tubuh yang akan digunakan untuk melakukan gerak. Menari memiliki beberapa unsur yang harus dikembangkan kemampuannya melalui latihan-latihan, kemampuan tubuh yang baik adalah hasil dari koordinasi unsur-unsur kondisi fisik yang baik. Unsur-unsur tersebut antara lain kekuatan, kecepatan, daya tahan, kelincahan, kelenturan, koordinasi, dan ketepatan. Dengan keterpenuhannya hal tersebut maka akan terbentuk keseimbangan gerak pada tubuh penari.

\section{METODE PENELITIAN \\ Jenis Penelitian}

Adapun penelitian ini menggunakan jenis penelitian evaluasi dengan metode deskriptif, dengan pendekatan kualitatif dan kuantitatif. Penelitian jenis evaluasi sebuah kegiatan pengumpulan data atau informasi, untuk dibandingkan dengan kriteria, kemudian diambil kesimpulan Arikunto (2017:36).

\section{Lokasi Dan Waktu Penelitian}

Lokasi penelitian di S1 olahraga Universitas Syiah Kuala Banda Aceh. Waktu penelitian akan dilaksanakan pada bulan November 2020.

\section{Subjek Penelitian}

Menurut arikunto (2006:145) Subjek peneliti adalah subjek yang dituju untuk diteliti oleh peneliti. Sani (2014:201) penilaian (judger) adalah proses menyimpulkan 
dan menafsirkan fakta-fakta serta membuat pertimbangan dasar yang profesional untuk mengambil kebijakan berdasarkan sekumpulan informasi.

\section{Instrumen Penelitian}

Adapun Instrumen dalam penelitian ini menggunakan skala penilaian, penilaian yang dibuat oleh peneliti.

\section{Teknik Analisi Data}

Setelah data didapatkan dan dikumpulkan, langkah selanjutnya adalah data diolah dengan menggunakan rumus persentase, setelah itu dilakukan penghitungan hasil rata- rata gerakan tari saman di tinjau dari konsep dasar dengan menggunakan rumus yang ada dibawah ini:

\section{Rumus Rata-Rata:}

$\bar{X}=\frac{\sum X}{N}$

Keterangan:

$\bar{X} \quad=$ Nilai Rata- rata

$\sum X=$ Jumlah Nilai $X$

$\mathrm{N} \quad=$ Sampel

\section{Rumus Persentase:}

$p=\frac{F}{n} \times 100 \%$

Keterangan:

$\mathrm{P} \quad=$ Persentase yang dicari

$\mathrm{F}=$ Frekwensi jawaban masing-masing option

$\mathrm{n}=$ Jumlah objek yang diteliti (sampel)

$100 \%=$ Nilai tetap (konstan)

Menjadikan tahapan-tahapan gerakan dapat dilihat dengan jelas dan rinci. Selanjutnya data di input dan di analisis untuk mengetahui dan memberikan sudutsudut serta gerakan tari saman di tinjau dari konsep dasar yang dilakukan subjek. Data yang berupa hasil formulir tes.

\section{HASIL DAN PEMBAHASAN PENELITIAN \\ Hasil Penelitian}

Berdasarkan hasil pelaksanaan pengukuran di lapangan melalui formulir tes tentang Gerakan Tari Saman dari tinjauan kebugaran jasmani Dan gerakan dasar yang di nilai oleh tim ahli yang berjumlah 5, diperoleh data mentah. Data tersebut selanjutnya ditabulasikan kedalam tabel untuk dapat memudahkan peneliti dalam proses pengolahannya. Pengelompokan data dalam tabel berupa data mentah Analisis Gerakan Tari Saman dari tinjauan kebugaran dan gerakan dasar.

Hasil penelitian yang diperoleh melalui formulir tes tentang gerakan Tari Saman dari tinjauan kebugaran jasmani dan gerakan dasar yang di nilai oleh tim ahli yang berjumlah 5 orang. Dari hasil pesentase gerakan tari saman di tinjau dari kebugaran jasmani terdapat daya tahan $12 \%$, keseimbangan $14 \%$, kelentukan $17 \%$, ketepatan $16 \%$, kecepatan 15\%, kelincahan 13\% dan kekuatan 13\%. 
Berdasarkan data hasil penelitian sebagaimana terdapat pada tabel hasil gerakan tari saman di tinjau dari gerakan dasar teknik analisis datanya. Dari hasil pesentase gerakan tari saman di tinjau dari gerakan dasar terdapat menekuk $18 \%$, membungkuk $15 \%$, menarik $19 \%$, memutar $17 \%$, mengangkat $17 \%$, dan mengayun $14 \%$.

\section{Pembahasan Penelitian}

Dari analisis gerakan tari saman oleh 5 orang tim ahli di atas berdasarkan 2 buah konsep yakni konsep kebugaran jasmani dan konsep gerakan dasar. Yang pertama di tinjau dari konsep kebugaran jasmani bahwa pada gerakan salam tari saman: terdapat daya tahan $12 \%$, keseimbangan $14 \%$, kelentukan $17 \%$, ketepatan $16 \%$, kecepatan $15 \%$, kelincahan 13\% dan kekuatan 13\%. Yang kedua di tinjau dari konsep gerakan dasar bahwa pada gerakan salam tari saman: terdapat menekuk $18 \%$, membungkuk $15 \%$, menarik 19\%, memutar $17 \%$, mengangkat $17 \%$, dan mengayun $14 \%$. Bagi penari kemampuna fisik yang baik adalah hasil koordinasi unsur-unsur kondisi fisik yang baik, ada pun kondisi yang baik yang perlu di persiapkan dan di latih adalah kekuatan, kecepatan, daya tahan, kelentukan, ketepatan dan koordinasi.

Tarian dapat menyehatkan tubuh, karena tari adalah aktifitas fisik yang lebih banyak melakuan gerak dengan kelincahan tubuh, kelenturan tubuh, daya tahan dan power yang akan benyak membakar energi dalam tubuh dan aktivitas kardiovaskular akan meningkat seperti kita berolahraga. Kesegaran jasmani adalah kemampuan untuk melakukan kegiatan atau pekerjaan sehari-hari dan adaptasi terhadap pembebanan fisik tanpa menimbulkan kelelahan berlebih dan masih mempunyai cadangan tenaga untuk menikmati waktu senggang maupun pekerjaan yang mendadak serta bebas dari penyakit (Depkes, 1994:25). Makin tinggi kemampuan fisik seseorang, makin mampu mengatasi beban kerja yang diberikan atau dengan kata lain kemampuan produktivitas orang tersebut makin tinggi (Depkes, 1987 pada jurnal Yuliana Noor Setiwati Ulvie, 2011:66).

Media ungkap tari adalah gerak. Gerak tari merupakan gerak yang diperhalus dan diberi unsur estetis. Gerak dalam tari berfungsi sebagai media untuk komunikasi. Kompetensi dasar dalam mempelajari seni tari mencakup praktik dasar dan mahir dalam penguasaan gerak tari meliputi tari tradisional maupun tari garapan, kemampuan memahami arah dan tujuan koreografer dalam konsep koreografi kelompok (Setiawati, 2008:62).

Saman merupakan sebuah tari tradisional yang berkembang secara turuntemurun di daerah Gayo Lues. Kegiatan saman dilakukan oleh laki-laki dalam posisi duduk bersimpuh dan kegiatan inti adalah gerakan tangan serta kepala dan jangin (syair). Syair dalam saman menggambarkan nilai kehidupan yang ada pada masyarakat Gayo, Dalam saman tentu ada nilai karena yang disebut seni memang nilai, bukan bendanya. Nilai adalah sesuatu yang bersifat subjektif, tergantung pada manusia yang menilainya, karena subjektif, setiap orang, setiap kelompok, dan setiap masyarakat memiliki nilai-nilainya sendiri.

\section{Kesimpulan}

Berdasarkan analisis hasil analisis data dan pembahasan dapat disimpulkan yaitu gerakan tari saman di tinjauh dari konsep kebugaran jasmani adalah terdapatnya 
daya tahan $12 \%$, keseimbangan 14\%, kelentukan 17\%, ketepatan 16\%, kecepatan $15 \%$, kelincahan 13\% dan kekuatan 13\%. Gerakan tari saman yang di tinjau dari konsep gerakan dasar: terdapat terdapat menekuk 18\%, membungkuk 15\%, menarik $19 \%$, memutar 17\%, mengangkat 17\%, dan mengayun 14\%. Tari saman adalah Simbol penandaan yang di dalamnya mengandung makna harfiah, bersifat primer dan langsung ditunjukkan. Namun Tari Saman juga mengandung makna lain yang bersifat sekunder dan tidak langsung yang biasanya. Tari Saman dapat berupa kiasan yang hanya dapat dipahami berdasarkan makna pertama. Sistem simbol sebagai intensionalitas ganda, pertama mengarah pada makna harfiah, dan kedua pada makna tersembunyi. Oleh karena itu simbol memerlukan interpretasi. Simbol gerak merupakan bentuk-bentuk gerakan yang diciptakan oleh masyarakat dengan berbagai ragam bentuk yang bersifat abstrak, sehingga masyarakatlah yang memberikan makna dari setiap bentuk simbol yang diciptakannya. Berbicara mengenai simbol dan makna dalam setiap gerak tari saman, hampir semua gerak yang ada memiliki simbol dan makna tersendiri yang tersirat di dalamnya. Penulis sulit mendapatkan data yang akurat mengenai simbol dan makna tersebut. Hal ini disebabkan di antaranya oleh minimnya tokoh-tokoh seniman yang memahami simbol dan makna dalam tari. Kondisi ini tidak terlepas dari kurangnya pemahaman para seniman dalam memahami setiap gerak-gerak tari yang mereka mainkan.

\section{DAFTAR PUSTAKA}

Agus Mukholid. (2004). Pendidikan Jasamani dan Olahraga.Jakarta: Yudistira Arikunto (2006). Metode Penelitian Kualitatif. Jakarta: Bumi Aksara.

Bahry. Rajab dan Samsul Bahri (2005). Tari Saman. Sejarah Pelaksanaan dan Nilai Syairnya (Naskah Ketik).

Bahry, Rajab (2014). Saman Kesenian Dari Tanah Gayo. Pusat Penelitian dan

Pengembangan Kebudayaan Jakarta, 2014.

Depkes RI. 2007. Pedoman Penyelenggaraan Pelayanan di Rumah Sakit.

Jakarta: Depkes RI.

Ismaryati. (2006). Tes dan Pengukuran Olahraga. Surakarta: Sebelas Maret.

Nala (2002). Prinsip Pelatihan Fisik Olahraga. Denpasar: Komite Olahraga Nasional Indonesia Daerah Bali.

Salam, Abd Ridhwan (2011). Tari Saman. Jakarta.

Sani (2014). Pembelajaran saintifik untuk kurikulum 2013. Jakarta: Bumi Aksara.

Syahroni, 2012, Teknik Pidato dalam Pendekatan Dakwah, Surabaya: Dakwah Digital Press.

Setiawati, S. (2008). Proses pembelajaran dalam pendidikan kesehatan. Jakarta: Trans info media.

Widiastuti (2017). Tes Dan Pengukuran Olahraga. PT. Raja Grafindo Persada, Jakarta. Wahjoedi (2001). Landasan Evaluasi Pendidikan Jasmani. Jakarta: Raja Grafindo Persada. 